\title{
Measuring Financial Performance of Student Enterpreneur's Business
}

\author{
Abdul Holik \\ Universitas Nasional Pasim \\ abdulcholiq20@ymail.com
}

\author{
Wala Erpurini \\ Universitas Nasional Pasim
}

\begin{abstract}
This research tries to explain the financial performance of several SMEs (Small Medium Enterprises) owned by our students. They are living examples of student that run business since in undergraduate program. The discourse to boosting SMEs cannot neglect problems related to financial performance. We obtained the result that the all financial statements showed good performance. Even though there were excess funds that the entrepreneurs not maximally used. We suspect they are doing it as a caution because they are still beginners in the business world. The businesses getting most profit are those who sell staple food substitutes. This phenomenon is because these types of foods are already familiar to most people's tongues. While businesses that focus on drinks with specific targets, it turns out shows smaller profits and even the lowest among others. However, in total, they showed their ability as entrepreneurs, even though on a small scale.
\end{abstract}

Keywords: Small Business; Student Entrepreneurs

\section{INTRODUCTION}

The discourse of entrepreneurship has recently been increasingly voiced, including by leaders in Indonesia (Antaranews.com, 2016). In line with this view, the theme of students' entrepreneurs today is also something quite important (Pikiran Rakyat, 2017). All agree that the spirit of entrepreneurship needs to be nurtured early, especially in the campus environment, business training requires a lot of practices. The idea of student entrepreneurs is not without reason. The students are educated groups who are believed to be able to leverage their potential to bring up the latest innovations and variations in all fields. In our academic world, we know the term that students as agents of change. They are bearers of the spirit of social order change around them, due to the brilliant thinking and challenging soul they have.

Many researchers have examined

the interests and intention of entrepreneurship among students. Some of them used the Theory of Planned Behavior approach (Muhammad, Haneef, \& Abubakar, 2013); (Ambad \& Damit, 2016). But there are relatively few studies focusing on pursuing entrepreneurs who are still students. At least the little research is due to those students always busy with learning activities on campus. So even though the intention to become entrepreneurs quite high, it is difficult for them to step into the business world consistently.

Empirical finding proves that entrepreneurial motivation is encouraged by the attitudes and environment of the students' family (Holik \& Manggala, 2016). The result means that the background factors of students are important enough to shape the attitude and mentality as strong as steel to become entrepreneurs in the future. Besides, of course, motivation in themselves must be nurtured from an early age. Selfmotivation is a significant motivating 
factor for a student to dare to enter entrepreneurship (Sivarajah \& Achchuthan, 2013).

Besides, empirical finding shows that work experience in the past could cause students to engage entrepreneurs rather than those who have never worked (Fatoki, 2014). Maybe one of the reason is that "trauma" and or the pressure of working for other people are less pleasant, encouraging them to prefer to build their own business. It is not weird that people who were in the long term worked as employees, in their adult year eager to be an entrepreneur because of bored.

This research focuses on the business that is currently booming, namely culinary. It is considered that this business is a lifelong business that has never dimmed. Food is a daily necessity, so there is no season disturbance while we run it properly. Now a number of our students have started their businesses. The first company (start-up) will forge them to become strong entrepreneurs in the future because they have been trained to carry out trading activities from an early age. The work they have done is still classified as SMEs (Small and Medium Enterprises), even at a certain level, the value is minimal. The initial effort that they worked on can be an essential learning platform for career choices as a great entrepreneur someday. We believe that entrepreneurship education, or seminars on entrepreneurship, will not mean much if the real action into the business world has not yet been tried.

Entrepreneurship is one of the essential pillars of the nation's economy. The more citizens enter the business world; the more economically prosperous the country will be. Index of Doing Business released by the World Bank has placed Indonesia in the $73^{\text {rd }}$ position out of 190 countries surveyed for the 2019 period, while Singapore is the second only to New Zealand as the first (The World
Bank, 2019). This value marks progress compared to the previous ten years ago which placed Indonesia in $127^{\text {th }}$ position in 2008 , and $129^{\text {th }}$ in 2009 from a total of 181 countries surveyed, while Singapore put in the first position above New Zealand as the second (The World Bank, 2008). By looking at this report, we believe that the potential for entrepreneurial development in Indonesia will increase year to year. The ease of doing business will grow the Indonesian economy and empower all of its citizens to be able to work more.

Maybe we should be more open in judging something. For example, why our neighboring countries like Singapore are always at the highest level. Its position is not at first, then the second. The ease of business is indeed very possible in the country due to various economic fundamental problems that are not as complicated as in Indonesia. On the other hand, empirical facts show us that there are differences in financial characteristics that include growth opportunities, nondebt tax shields, firm size, tangibility, and liquidity, among companies in the ASEAN region (Hadinugroho et al., 2018). This fact reminds us that it is implausible to impose a uniformity of characteristics, including in capital structure, for various companies even though in the same area.

The importance of this research is because we want to test the sustainability of the observed trend of entrepreneurship among the youth. We focus on financial performance. We believe that good business is one that has endurance and produces continuous profits. Entrepreneurship education finds it real benefits when students being brave to go directly running a business. The specific purpose is to find the pattern and living examples of students who have undergone their business, despite a small proportion. 
From there we can see their potential to become strong entrepreneurs in the future.

\section{LITERATURE REVIEW}

Empirical research finds interesting facts that sometimes some problems often faced by the young entrepreneurs graduated from university when they start businesses, namely: the problem of finance, employment, marketing, and equipment (Budiyanti \& Patiro, 2015). Meanwhile, legal issues are not too problematic. The four issues are indeed quite complicated because it requires us to be able to develop our potential very tightly. For example, we cannot rely on marketing issues to open our store and wait for the customers to come. We must be able to attract them to go and buy our products.

Due to business is a challenging field, maintaining customers' loyalty should be a priority to obtain success. One expert concluded that the loyalty of Muslim customers to Islamic banking services influenced by their satisfaction and trust (Darmawan, 2018). Meanwhile, other factors such as company image, gender, age, education, and work, do not affect loyalty. Form these findings we can understand that satisfaction and trust occupy a significant proportion to attract the highest possible customer loyalty. Newly started businesses certainly face this problem, because they may not be known very well for many people. They should make some strategic marketing plans.

To increase business potential, entrepreneurs need to improve the company's fixed assets. Empirical research found that the structure of fixed assets positively influences the company's capital structure (Sutrisno, 2016). It means that the higher the fixed assets, the more capital accumulated for business expansion. By spreading our business units, we can be able to get more profits.

Because the field of
entrepreneurship always faces uncertainty, to create long-lasting entrepreneurs we need to grow courage and bravery. One study concluded that the intention of entrepreneurship among the students was influenced by their attitudes, confidence, and bravery to take risks (Wijaya et al., 2015). This finding is understandable because the world of entrepreneurship is full challenges and uncertainties. Being strong entrepreneurs needs strong determination and mentality as hard as steel in facing all obstacles. Intellectual intelligence alone is not enough if the courage to start is absent.

Besides, competitiveness is also essential for our business can be sustainable in the long-term. Business strategy quality and seller behavioral ethics have a partial influence toward a competitive advantage for SMEs (Small and Medium Enterprises) in Central Java (Asyhari et al., 2018). This research conducted by the case of small entrepreneurs in the field of batik as local creative products. It is also noted that besides business strategy quality and seller behavioral, process innovation, entrepreneurship orientation perspective, business environment adaptability, and partial competitive advantage, proven have a significant effect on business performance.

Other research also reminds us that financial literacy has a positive impact on the performance and sustainability of creative SMEs (Small and Medium Enterprises) in Central Java (Aribawa, 2016). This finding confirms that when financial literacy rises, SMEs players can make appropriate management and financial decisions to advance their business.

The SMEs is a vulnerable business sector due to shocks that will 
happen around it. So the performance of this sector must be supported by good management. Empirical research has found that internal integration and information sharing have a significant positive effect on supply chain performance (Mufaqih, Indarti, Ciptono, \& Kartikasari, 2017). Uniquely, the postponement has a negative impact on supply chain performance. This finding proves that internal integration and information sharing are critical in advancing SMEs, especially in the field of batik, because it supports the acceleration of the performance of business actors in making a better decision.

We should remember that business progress must consider supply chain capability which is a significant role in the business performance of SMEs (Small and Medium Enterprises). Research by a case in Yogyakarta stated that all operational capabilities including three dimensions (supply chain capability including structural, logistical, and technological capability) have a significant positive impact both partially and wholly in business performance (Prastia \& Nursyamsiah, 2016).

Besides being supported by good management factors, an important point of business progress especially SMEs is the ability of company leaders or CEO to run their businesses. The proof of research involving 86 SMEs (Small and Medium Enterprises) of handicrafts, shows that transformational leadership effects are positive on the organizational leadership (Lita et al., 2018). The transformational leader who can prepare the next leadership generation can support the improvement of company performance. Besides, the market orientation that is reflected by relationship to customers, resources orientation, and competitor orientation has proven to have a significant positive influence on the organizational innovation and organizational performance.
Other findings also mention that business orientation and sound financial performance need to involve great owner characteristics (Ismanto, Aziz, \& Irawan, 2018). This research finding in 160 trosowoven SMEs confirmed the general belief that without the firmness and active principles of owners, SMEs would quickly go into bankrupt, because they could not compete with existing and large companies.

It is also concluded that knowledge sharing has a significant positive effect on absorptive capacity, and innovation ability (Ranto, 2015). In some degree, it is urgent, that different levels of innovation require different microsensing elements to be emphasized. More innovative companies need more intensive sensing than less innovative companies (Priyono, Nursyamsiah, \& Darmawan, 2018). Micro-Sensing is research and development. Without the initiation to absorb the progress of human civilization, business is undoubtedly challenging to develop.

If in the current situation the information and communication technology have become increasingly more sophisticated, SMEs which are not ready will lost great opportunities. They should prepare themselves to be prepared in facing any breakthrough in technology. The advancement of technology cannot be stopped; rather we should be able to adapt everything come up from it. Scientific research proves a significant positive effect of the organizational readiness and perceived benefits on e-commerce adoption of SMEs creative industries (Syah et al., 2016). Here we can see the opportunity to use digital technology needs to be supported by a better campaign. The government should provide proper regulation that makes SMEs more developed.

However, the problem is sometimes the implementation of 
government policies in supporting the progress of SMEs has not been optimally distributed evenly in all regions. The result of the study stated that the implementation of the corporate governance mechanism in the greatest Malang was quite limited (Jaswadi, 2017).

The application which was not widespread yet implies the need for direction and assistance from the government to advance SMEs to be more developed and survive in the future.

Business sometimes requires cooperation with various parties. Nonetheless, we must observe, with the kind of companies we want to partner. Empirical research found that internationalization had a negative effect on company performance - reflected by ROA (Return on Assets) and Tobin's Q. Meanwhile the number of business affiliates negatively affected Tobin's Q, but it had a positive impact on ROA. Interestingly, the company's international affiliation and the intensity of research and development showed positive signs of ROA and Tobin's Q (Chadys, Sulung, \& Admeinasthi, 2018). From these findings, we believe that sales of overseas companies are less competitive, due to a lack of success in marketing and cost efficiency. This matter is reinforced by the negative influence of business affiliation on Tobin's Q. Affiliation with evil companies will induce lousy image, and eventually will generate a shortage of profits.

The role of any business owner cannot be ignored. Information and communication openness enables the company to open the most extensive possible space for a broader public to know. Empirical facts from expert study find that disclosure (both voluntary and coercive) and concentration of ownership have a negative impact on the cost of equity capital (Kusumawardhani, 2018). Meanwhile, the diversification of business reflected by the Herfindahl index shows us the significant positive effect on the cost of equity capital.

The company's commissioner structure is sometimes considered to have an impact on earnings management in the company. The result of the study obtained evidence that female commissioner, independent commissioner, and board of commissioners' tenure did not affect profit management. Meanwhile, the size of the board of commissioners and the age of board members have a significant negative effect on profit management (Setiawan, 2018). The findings in this study confirm the belief that more commissioners can minimize profit management. Likewise with the age of board members who are older, indicating more experiences they have, can minimize the company's profit management.

The strength of this research can be seen that we scrutinize the study among the students who have plunged and acted as entrepreneurs, even though in the micro business level. So that we do not just talk about the theory of how to become an entrepreneur, but rather test, evaluate, and assist the student entrepreneurs to succeed. Although both are engaged in the food sector, this research tries to seek to explain what businesses produce the most profits and what the patterns look. Since the respondents are the students that we taught on campus, we wanted them to be tough entrepreneurs in the future, with the provision they got while at the university.

\section{METODHOLOGY}

This study uses a descriptive approach for case studies of young entrepreneurs at the university level. We choose the descriptive method because it was more appropriate in this study, as one way of explaining problems based on data, analyzing and describing them 
clearly (Creswell, 2009); (Walliman \& Baiche, 2001).

The focus of this study is an analysis of the financial performance of the small business. According to the Republic of Indonesia's law number 20 (UU No. 20), year 2008 about micro, small, and medium businesses (UMKM), a company called micro business if it has a net worth of at most 50 million rupiahs, not including land and buildings, or having results of annual sales of at most 300 million rupiah. In other cases, it has yearly sales of no more than 300 million rupiahs to a maximum of $\mathrm{Rp}$ 2,500,000,000. While medium-sized businesses are types of companies that have a net worth of more than 500 million rupiahs to a maximum of 10 billion rupiahs, not including land and business buildings. In other cases, it has annual sales of more than $R p 2,500,000,000$ to a maximum of 50 billion rupiah.

Based on the explanation above, the business run by students in this study is a micro business. They started a business from little capital, even under millions of rupiah. If there is another criterion that lower than micro business, their business can be called pico business.

To find out the endurance in business, we can trace its financial statements. Financial statements are significant for business continuity, no matter whether the company is small or large. The financial statements consist of various financial transaction reports carried out during the year. Financial statements are vital because they reflect the financial condition and results of the company's operations. Financial reports are useful in providing various information regarding the financial position and performance of a company. From the financial statements, entrepreneurs can make important decisions concerning the sustainability of their business.
One of the essential tools in evaluating company performance is a measure of a company's financial performance, which includes:

a. The liquidity ratio, a measure of corporate performance assessment used to measure a company's ability to pay debts.

b. The leverage ratio, a measure of corporate performance assessment used to measure how much the company will finance the assets.

c. The activity ratio, this used to measure how effective the company is applying its funding sources.

d. The profitability ratio shows the final results of some policies and decisions that have been taken by company management.

From the ratio above, there are several indicators that need to be considered, namely: liquidity ratio (current ratio, fast ratio, and cash ratio); leverage ratio (debt ratio, and debt ratio to capital); asset ratio (inventory turnover, fixed assets turnover, and total assets turnover); and profitability ratio (gross profit margin, net profit margin, ROA, and ROE).

The object of our research is a small entrepreneurship group run by our several students in Bandung, West Java. We choose them because they can be example of entrepreneurs since in the undergraduate study. Because they start running the business, not at the same time, so we only analyze it in cross-section, not in a time series style. The primary data used here obtained from the results of the financial statements of each entrepreneur. There are 10 (ten) students as research respondents. They primarily have business in food.

Their financial report data are taken during July 2018. We deliberately chose this period, given the right times was taken during the college vacation time, so they could concentrate on 
working to their business. Also, we did not carry out time series rather crosssection because they started a business, not at the same time or period. There are those who have more than five months running the business, meanwhile some others just two months. So we choose a period that allows for a stable situation and condition, namely only in July 2018.

\section{RESULT}

The results of the analysis in this study are based on the financial statements of the average young entrepreneurs consisting of the following:

1) Liquidity Ratio

\begin{tabular}{|l|l|l|l|}
\hline \multicolumn{4}{|c|}{ Table 1. Current Ratio (1 p roduction) } \\
\hline & $\begin{array}{l}\text { Current } \\
\text { Assets }\end{array}$ & $\begin{array}{l}\text { Current } \\
\text { Liabilitie s }\end{array}$ & $\begin{array}{l}\text { Current } \\
\text { Ratio }\end{array}$ \\
\cline { 2 - 4 } & A & b & $(\mathrm{a}$ b) $\times 100 \%$ \\
\hline YI & 65,000 & $2,000.00$ & $3250.00 \%$ \\
\hline EL & 42,000 & $1,000.00$ & $4200.00 \%$ \\
\hline PS & 47,500 & $1,500.00$ & $3166.67 \%$ \\
\hline YN & 54,000 & $1,000.00$ & $5400.00 \%$ \\
\hline MK & 200,000 & $15,000.00$ & $1333.33 \%$ \\
\hline YF & 209,000 & $1,000.00$ & $20900.00 \%$ \\
\hline KC & 132,000 & $2,000.00$ & $6600.00 \%$ \\
\hline KR & 35,000 & $3,000.00$ & $1166.67 \%$ \\
\hline BS & 75,000 & $1,500.00$ & $5000.00 \%$ \\
\hline SH & 92,000 & $3,500.00$ & $2628.57 \%$ \\
\hline & & & \\
\hline & 951,500 & 31,500 & 536 \\
\hline average & $\mathbf{9 5 , 1 5 0}$ & $\mathbf{3 , 1 5 0}$ & $\mathbf{5 3 6 4 . 5 2} \%$ \\
\hline
\end{tabular}

In table 1 , it is known that current ratio in all business activities is tremendous. Among all the fields they are working on, the biggest is $\mathrm{YF}$, which is $20,900 \%$. The value of the current ratio at a certain point indicates that all these businesses face over liquidity.

The less optimal performance of the company can indicate management weaknesses and inefficiencies in utilizing current assets. Supposedly, with the funds they have, the students' efforts can be more significant and have high aggressiveness in pursuing consumers.

Indeed, with the existence of this report, we are also pleased because the entrepreneurial students dare to do business with their capital and minimize debts. We need to give them a briefing about what the prospects are so that the funds they have now can be used for business development.

\begin{tabular}{|l|l|l|l|l|}
\hline \multicolumn{5}{|c|}{ Table 2. Quick Ratio } \\
\hline & $\begin{array}{l}\text { Current } \\
\text { Asset }\end{array}$ & Inventory & $\begin{array}{l}\text { Current } \\
\text { Liabilities }\end{array}$ & $\begin{array}{l}\text { Current } \\
\text { Ratio }\end{array}$ \\
\cline { 2 - 5 } & a & B & C & $\begin{array}{l}(\text { (a-b)/c) x } \\
100 \%\end{array}$ \\
\hline YI & 65,000 & 21,000 & 2,000 & $2200.00 \%$ \\
\hline EL & 42,000 & 11,000 & 1,000 & $3100.00 \%$ \\
\hline PS & 47,500 & 9,600 & 1,500 & $2526.67 \%$ \\
\hline YN & 54,000 & 10,000 & 1,000 & $4400.00 \%$ \\
\hline MK & 200,000 & 11,000 & 15,000 & $1260.00 \%$ \\
\hline YF & 209,000 & 22,000 & 1,000 & $18700.00 \%$ \\
\hline KC & 132,000 & 13,000 & 2,000 & $5950.00 \%$ \\
\hline KR & 35,000 & 5,000 & 3,000 & $1000.00 \%$ \\
\hline BS & 75,000 & 7,000 & 1,500 & $4533.33 \%$ \\
\hline SH & 92,000 & 8,500 & 3,500 & $2385.71 \%$ \\
\hline & & & & \\
\hline & 951,500 & 118,100 & 31,500 & 460.56 \\
\hline average & $\mathbf{9 5 , 1 5 0}$ & $\mathbf{1 1 , 8 1 0}$ & $\mathbf{3 , 1 5 0}$ & $\mathbf{4 6 0 5 . 5 7 \%}$ \\
\hline
\end{tabular}

Table 2 shows what is almost the same as the current ratio, i.e., business owners are less aggressive in managing their inventory. The highest value is YF business which is $18,700 \%$, while the smallest is the KR business which is $1000 \%$.

YF is a business engaged in soft drinks familiar enough to young people especially students: milkshakes. While $\mathrm{KR}$ is processed food that can be a staple food substitute, it can be enjoyed and familiar enough by anyone, both children, students, and adults. The most visible business capable of utilizing its resources is $\mathrm{KR}$, seen from its small ratio. 


\begin{tabular}{|l|l|l|l|}
\hline \multicolumn{4}{|c|}{ Table 3. Cash Ratio } \\
\hline & Cash & $\begin{array}{l}\text { Current } \\
\text { Liabilities }\end{array}$ & Cash Ratio \\
\hline & $\mathrm{a}$ & $\mathrm{b}$ & $(\mathrm{a} / \mathrm{b}) \times 100 \%$ \\
\hline YI & 33,000 & 2,000 & $1650.00 \%$ \\
\hline EL & 19,000 & 1,000 & $1900.00 \%$ \\
\hline PS & 21,000 & 1,500 & $1400.00 \%$ \\
\hline YN & 20,000 & 1,000 & $2000.00 \%$ \\
\hline MK & 95,000 & 15,000 & $633.33 \%$ \\
\hline YF & 102,000 & 1,000 & $10200.00 \%$ \\
\hline KC & 59,000 & 2,000 & $2950.00 \%$ \\
\hline KR & 12,000 & 3,000 & $400.00 \%$ \\
\hline BS & 29,500 & 1,500 & $1966.67 \%$ \\
\hline SH & 41,000 & 3,500 & $1171.43 \%$ \\
\hline & 431,500 & 31,500 & 242.7142857 \\
\hline & & & \\
\hline average & $\mathbf{4 3 , 1 5 0}$ & $\mathbf{3 , 1 5 0}$ & $\mathbf{2 4 2 7 . 1 4 \%}$ \\
\hline
\end{tabular}

Based on table 3, we obtain information on a relatively large cash ratio report. The biggest value is the same as in tables 1 and 2, namely the YF business of $10,200 \%$. Meanwhile, the smallest value returned by the KR business, amounting to $400 \%$. From here, we can see that the most ineffective industry is YF because the ratio is too large compared to the others. It seems that YF unable to maximize its potency.

Interestingly, the business run by $\mathrm{KR}$ can maximally be enhanced by its owner, as evidenced by the smallest liquidity ratio. Probably it is because the consumer segment was always increasing. People still need food, so business is never quiet.

\section{2) Leverage Ratio}

\begin{tabular}{|c|c|c|c|}
\hline & $\begin{array}{l}\text { Total } \\
\text { Debt }\end{array}$ & $\begin{array}{l}\text { Total } \\
\text { Assets }\end{array}$ & Debt Ratio \\
\hline & $\mathrm{a}$ & $\mathrm{b}$ & $(\mathrm{a} / \mathrm{b})^{*} 100 \%$ \\
\hline YI & 2,000 & 120,000 & $1.67 \%$ \\
\hline EL & 1,000 & 94,000 & $1.06 \%$ \\
\hline PS & 1,500 & 102,000 & $1.47 \%$ \\
\hline $\mathrm{YN}$ & 1,000 & 150,000 & $0.67 \%$ \\
\hline MK & 15,000 & 450,000 & $3.33 \%$ \\
\hline YF & 1,000 & 550,000 & $0.18 \%$ \\
\hline $\mathrm{KC}$ & 2,000 & 190,000 & $1.05 \%$ \\
\hline $\mathrm{KR}$ & 3,000 & 99,000 & $3.03 \%$ \\
\hline BS & 1,500 & 150,000 & $1.00 \%$ \\
\hline $\mathrm{SH}$ & 3,500 & 210,000 & $1.67 \%$ \\
\hline & 31,500 & $2,115,000$ & 0.151325041 \\
\hline average & 3,150 & 211,500 & $1.51 \%$ \\
\hline
\end{tabular}

Table 4 above describes the debt ratio of all food businesses belonging to student entrepreneurs. The business MK shows the highest value of debt ratio at $3.33 \%$. Meanwhile, the smallest indicated by the YF business of $0.18 \%$. MK runs a snack business: lumpia. This type of food is not a substitute for staple food at all, nor is it a food that has branded stylish for the young generation.

The small value of debt ratio shows the small amount of the loan that must be paid by the business owners. It means that at a certain level, it might be a positive side that needs to be appreciated because the business actors are students who are still busy studying. They are still learning to do business slowly, and are very careful in managing finances.

\begin{tabular}{|l|l|l|l|}
\hline \multicolumn{3}{|l}{ Table 5. Debt Ratio to Capital } \\
\hline & $\begin{array}{l}\text { Total } \\
\text { Debt }\end{array}$ & Total Capital & $\begin{array}{l}\text { Debt } \\
\text { Ratio to } \\
\text { Capital }\end{array}$ \\
\cline { 2 - 4 } & a & b & $\begin{array}{l}(\mathrm{a} / \mathrm{b}) \\
100 \%\end{array}$ \\
\hline YI & $2,000.00$ & $115,000.00$ & $1.74 \%$ \\
\hline EL & $1,000.00$ & $90,000.00$ & $1.11 \%$ \\
\hline PS & $1,500.00$ & $98,000.00$ & $1.53 \%$ \\
\hline YN & $1,000.00$ & $130,000.00$ & $0.77 \%$ \\
\hline MK & $15,000.00$ & $410,000.00$ & $3.66 \%$ \\
\hline YF & $1,000.00$ & $495,000.00$ & $0.20 \%$ \\
\hline KC & $2,000.00$ & $175,000.00$ & $1.14 \%$ \\
\hline KR & $3,000.00$ & $89,000.00$ & $3.37 \%$ \\
\hline BS & $1,500.00$ & $135,000.00$ & $1.11 \%$ \\
\hline SH & $3,500.00$ & $186,000.00$ & $1.88 \%$ \\
\hline & & & \\
\hline average & $\mathbf{3 , 1 5 0}$ & $\mathbf{1 9 2 , 3 0 0}$ & $\mathbf{1 . 6 5} \%$ \\
\hline
\end{tabular}

Table 5 tells us that the smallest ratio is by YF business of $0.20 \%$, while the biggest is MK business with a value of $3.66 \%$. KR business occupies the second position from the top, amounting to 3.37 $\%$. The average of this ratio is small, $1.65 \%$. This low ratio value indicates that 
entrepreneurs do not take much financing from the outside. The entrepreneurs who manage their business seems to rely more on their capital. This quite right, because it means that their company has little risk.

By considering the business they are running is still in its early stages; presumably, this financial report does not matter. We see the enormous potential of these student entrepreneurs because they already want to do bookkeeping, including in debt matters, even though the value relatively small.

\section{3) Asset Ratio}

\begin{tabular}{|l|l|l|l|l|}
\hline \multicolumn{5}{|c|}{ Table 6. Inventory Turnover } \\
\hline \multirow{2}{*}{} & HPP & Inventory & $\begin{array}{l}\text { Average } \\
\text { Inventory }\end{array}$ & $\begin{array}{l}\text { Inventory } \\
\text { Turnover }\end{array}$ \\
\cline { 2 - 5 } & $\mathrm{A}$ & $\mathrm{B}$ & $\mathrm{c}$ & $\begin{array}{l}(\mathrm{a} / \mathrm{b}) \mathrm{x} 1 \\
\text { time }\end{array}$ \\
\hline YI & $105,000.00$ & $21,000.00$ & 5 & $5.00 \mathrm{t}$ \\
\hline EL & $88,000.00$ & $11,000.00$ & 8 & $8.00 \mathrm{t}$ \\
\hline PS & $89,500.00$ & $9,600.00$ & 9.32 & $9.32 \mathrm{t}$ \\
\hline YN & $115,000.00$ & $10,000.00$ & 11.5 & $11.50 \mathrm{t}$ \\
\hline MK & $388,000.00$ & $11,000.00$ & 35.27 & $35.27 \mathrm{t}$ \\
\hline YF & $488,000.00$ & $22,000.00$ & 22.18 & $22.18 \mathrm{t}$ \\
\hline KC & $169,000.00$ & $13,000.00$ & 13 & $13.00 \mathrm{t}$ \\
\hline KR & $80,000.00$ & $5,000.00$ & 16 & $16.00 \mathrm{t}$ \\
\hline BS & $125,000.00$ & $7,000.00$ & 17.86 & $17.86 \mathrm{t}$ \\
\hline SH & $177,000.00$ & $8,500.00$ & 20.82 & $20.82 \mathrm{t}$ \\
\hline & $1,824,500.00$ & $118,100.00$ & 158.96 & 158.96 \\
\hline & & & & \\
\hline average & $\mathbf{1 8 2 , 4 5 0}$ & $\mathbf{1 1 , 8 1 0}$ & & $\mathbf{1 5 . 9 0 \mathrm { t }}$ \\
\hline
\end{tabular}

Table 6 above shows us that the business inventory turnover of student entrepreneurs is relatively diverse. The average value is 15.90 times. The biggest is the business of the MK which is 35.27 times. Meanwhile, the smallest is the YI business of 5 times. Looking at these data, we obtain confirmation that business run by students is quite well. The magnitude of the value means that the inventory is often used, and not much kept quiet.

Conversely, the low turnover indicates that companies prefer to hold an extensive inventory, which is less effective in business progress. Of the total ten financial statements presented here, only three seemed to be ineffective in using their stock, namely YI, EL, and PS. Their values are below ten times, respectively. The owners of these three businesses must be guided and directed so that they prefer to use inventory for business development.

\begin{tabular}{|l|l|l|l|}
\hline \multicolumn{4}{|l}{ Fixed Asset Turnover } \\
\hline & Sales & Fixed Asset & $\begin{array}{l}\text { Fixed } \\
\text { Asset } \\
\text { Turnover }\end{array}$ \\
\hline & a & b & $\begin{array}{l}(\mathrm{a} / \mathrm{b}) \mathrm{x} \\
\text { time (t) }\end{array}$ \\
\hline YI & $167,000.00$ & 17,000 & $9.82 \mathrm{t}$ \\
\hline EL & $135,000.00$ & 18,000 & $7.50 \mathrm{t}$ \\
\hline PS & $144,000.00$ & 19,500 & $7.38 \mathrm{t}$ \\
\hline YN & $154,000.00$ & 21,000 & $7.33 \mathrm{t}$ \\
\hline MK & $421,000.00$ & 19,000 & $22.16 \mathrm{t}$ \\
\hline YF & $520,000.00$ & 30,000 & $17.33 \mathrm{t}$ \\
\hline KC & $198,000.00$ & 35,000 & $5.66 \mathrm{t}$ \\
\hline KR & $139,000.00$ & 9,500 & $14.63 \mathrm{t}$ \\
\hline BS & $177,000.00$ & 27,000 & $6.56 \mathrm{t}$ \\
\hline SH & $225,000.00$ & 21,000 & $10.71 \mathrm{t}$ \\
\hline & $2,280,000.00$ & $217,000.00$ & 109.09 \\
\hline & & & \\
\hline average & $\mathbf{2 2 8 , 0 0 0 . 0 0}$ & $\mathbf{2 1 , 7 0 0 . 0 0}$ & $\mathbf{1 0 . 9 1 ~ t}$ \\
\hline
\end{tabular}

Table 7 describes the conditions of fixed asset turnover of various businesses carried out by student entrepreneurs. The lowest turnover is $\mathrm{KC}$ with a value of 5.66 times turnover. Meanwhile, the value obtained by MK is 22.16 times. Both of these businesses are developing traditional foods that are known by the surrounding community. MK sold lumpia (spring rolls). KC sold karedok - a type of local food in the form of raw vegetables with chili sauce.

Table 7 also tells us that the amount of fixed assets is not always in line with the number of sales. In the table, the highest sales are YF, with a value of IDR 520,000. However, the amount of fixed assets is not too high, only 17.33 times. The number of fixed assets must be balanced with an increase in sales because it indicates the 
use of resources maximized in the production process. If in the next period, sales are higher, but fixed assets do not rise, showing a decrease in fixed assets. It is not very good for the company.

\begin{tabular}{|l|l|l|l|}
\hline \multicolumn{4}{|l|}{ Total Asset Turnover } \\
\hline & Sales & $\begin{array}{l}\text { Tota1 } \\
\text { Asset }\end{array}$ & $\begin{array}{l}\text { Total Asset } \\
\text { Turnover }\end{array}$ \\
\hline & A & b & (a/b)x 1 time \\
\hline YI & $167,000.00$ & 120,000 & 1.39 times \\
\hline EL & $135,000.00$ & 94,000 & 1.44 times \\
\hline PS & $144,000.00$ & 102,000 & 1.41 times \\
\hline YN & $154,000.00$ & 150,000 & 1.03 times \\
\hline MK & $421,000.00$ & 450,000 & 0.94 times \\
\hline YF & $520,000.00$ & 550,000 & 0.95 times \\
\hline KC & $198,000.00$ & 190,000 & 1.04 times \\
\hline KR & $139,000.00$ & 99,000 & 1.40 times \\
\hline BS & $177,000.00$ & 150,000 & 1.18 times \\
\hline SH & $225,000.00$ & 210,000 & 1.07 times \\
\hline & & & \\
\hline & $2,280,000.00$ & $2,115,000$ & 11.84 \\
\hline & & & \\
\hline average & $\mathbf{2 2 8 , 0 0 0 . 0 0}$ & $\mathbf{2 1 1 , 5 0 0 . 0 0}$ & $\mathbf{1 . 1 8}$ times \\
\hline
\end{tabular}

Table 8 shows us the relatively different value of total assets turnover. The highest amount is the EL business, 1.44 times, while the smallest is the MK business, 0.94 times. YF and MK businesses interestingly have a sales value greater than total assets. It indicates that both enterprises are not optimally using their assets in the production process. The business owners need to be directed and guided so that they dare to set high-profit targets through radical business expansion. Although of course, we see that owners or the two businesses tend apparently to be very careful in making business decisions.

Another critical point is the difference in the ability of entrepreneurs to adapt and adjust conditions to increase their sales. The ability to sell is the key to business continuity to survive in the longterm. Of course here the marketing paradigm must be formed so that that seller's mentality is embedded in their minds. A good business is one that can generate extensive sales, with values that continue to increase over time, so that profits will improve too.

\section{4) Profitability Ratio}

\begin{tabular}{|l|l|l|l|}
\hline \multicolumn{3}{|l}{ Margin of Gross Profit } & $\begin{array}{l}\text { Margin } \\
\text { of Gross } \\
\text { Profit }\end{array}$ \\
\hline & $\begin{array}{l}\text { Gross } \\
\text { Profit } \\
\text { (sales-hpp) }\end{array}$ & sales & $\begin{array}{l}\text { (a/b) x } \\
100 \%\end{array}$ \\
\cline { 2 - 4 } & A & b & $37.13 \%$ \\
\hline YI & $62,000.00$ & $167,000.00$ & $34.81 \%$ \\
\hline EL & $47,000.00$ & $135,000.00$ & $37.85 \%$ \\
\hline PS & $54,500.00$ & $144,000.00$ & $25.32 \%$ \\
\hline YN & $39,000.00$ & $154,000.00$ & $7.84 \%$ \\
\hline MK & $33,000.00$ & $421,000.00$ & $6.15 \%$ \\
\hline YF & $32,000.00$ & $520,000.00$ & $14.65 \%$ \\
\hline KC & $29,000.00$ & $198,000.00$ & $42.45 \%$ \\
\hline KR & $59,000.00$ & $139,000.00$ & $29.38 \%$ \\
\hline BS & $52,000.00$ & $177,000.00$ & $21.33 \%$ \\
\hline SH & $48,000.00$ & $225,000.00$ & 2.569092 \\
\hline & $455,500.00$ & $2,280,000.00$ & 2.56 \\
\hline & & & \\
\hline average & $\mathbf{4 5 , 5 5 0 . 0 0}$ & $\mathbf{2 2 8 , 0 0 0 . 0 0}$ & $\mathbf{2 5 . 6 9 \%}$ \\
\hline
\end{tabular}

Based on the findings in table 9, it informs us that the gross profit margin is quite diverse enough. The lowest margin indicated by YF which was $6.15 \%$. The second low position occupied by MK business which was $7.84 \%$. YF and MK businesses are not much different, due to they require more expertise in preparing dishes, utensils, and also ingredients. They spent a lot more money since the beginning of the business.

Compared to the KR business, for example, MK and YF made a little profit. $\mathrm{KR}$, which sells dumplings (pangsit) and various other complementary foods, clearly gets more significant benefits, because the customers are not limited to a specific segment of people. It also has been familiar to the public's tongue. 


\begin{tabular}{|c|c|c|c|}
\hline \multicolumn{4}{|c|}{ Margin of Net Profit } \\
\hline & Net Profit & Sales & $\begin{array}{c}\text { Margin } \\
\text { of Net } \\
\text { Profit }\end{array}$ \\
\cline { 2 - 4 } & A & b & $\begin{array}{c}\text { (a/b) } \mathrm{x} \\
100 \%\end{array}$ \\
\hline YI & $58,000.00$ & $167,000.00$ & $34.73 \%$ \\
\hline EL & $31,000.00$ & $135,000.00$ & $22.96 \%$ \\
\hline PS & $48,000.00$ & $144,000.00$ & $33.33 \%$ \\
\hline YN & $20,500.00$ & $154,000.00$ & $13.31 \%$ \\
\hline MK & $19,000.00$ & $421,000.00$ & $4.51 \%$ \\
\hline YF & $18,000.00$ & $520,000.00$ & $3.46 \%$ \\
\hline KC & $11,000.00$ & $198,000.00$ & $5.56 \%$ \\
\hline KR & $49,000.00$ & $139,000.00$ & $35.25 \%$ \\
\hline BS & $45,000.00$ & $177,000.00$ & $25.42 \%$ \\
\hline SH & $39,500.00$ & $225,000.00$ & $17.56 \%$ \\
\hline & $339,000.00$ & $2,280,000.00$ & 1.96 \\
\hline average & $\mathbf{3 3 , 9 0 0 . 0 0}$ & $\mathbf{2 2 8 , 0 0 0 . 0 0}$ & $\mathbf{1 9 . 6 1} \%$ \\
\hline
\end{tabular}

Based on the calculation of net profit margin, the business that student entrepreneurs engage in shows different benefits. The biggest one can be seen in table 10, which is the KR business of $35.25 \%$, while the second position is YI business of $34.73 \%$. The KR and YI businesses are both engaged in food with different specifications. KR sells dumplings (pangsit), meatballs (bakso) and other accessories. Meanwhile, YI sells chilies-cireng.

Uniquely, the YF business shows the lowest profit margin again, as the same as in table 9. The main reason is that YF business in the field of soft drinks requires a lot of compounding costs compared to both. It shows evidence that the food business which is a substitute for rice still being the superior product in the food industry.
One way to increase YF's business profit margin is to use all its potential by increasing market share. The basic concept of economies of scale must be compiled, namely by increasing production and selling. That is a way, we can raise the net profit margin due to rising profits, and finally, the production costs will be considered small.

\begin{tabular}{|l|l|l|l|}
\hline \multicolumn{4}{|l|}{ ROA } \\
\hline \multirow{2}{*}{} & Net Profit & $\begin{array}{l}\text { Total } \\
\text { Asset }\end{array}$ & ROA \\
\cline { 2 - 4 } & a & b & $(\mathrm{a} / \mathrm{b}) \times 100 \%$ \\
\hline YI & $58,000.00$ & 120,000 & $48.33 \%$ \\
\hline EL & $31,000.00$ & 94,000 & $32.98 \%$ \\
\hline PS & $48,000.00$ & 102,000 & $47.06 \%$ \\
\hline YN & $20,500.00$ & 150,000 & $13.67 \%$ \\
\hline MK & $19,000.00$ & 450,000 & $4.22 \%$ \\
\hline YF & $18,000.00$ & 550,000 & $3.27 \%$ \\
\hline KC & $11,000.00$ & 190,000 & $5.79 \%$ \\
\hline KR & $49,000.00$ & 99,000 & $49.49 \%$ \\
\hline BS & $45,000.00$ & 150,000 & $30.00 \%$ \\
\hline SH & $39,500.00$ & 210,000 & $18.81 \%$ \\
\hline & 339,000 & $2,115,000$ & 2.53626443 \\
\hline & & & \\
\hline average & $\mathbf{3 3 , 9 0 0}$ & $\mathbf{2 1 1 , 5 0 0}$ & $\mathbf{2 5 . 3 6 \%}$ \\
\hline
\end{tabular}

Based on table 11 above, it is known that the highest ROA is KR business which is $49.49 \%$. It is proof that trade in staple food does not recognize the word dead as long as we are patient and diligent in running it. Especially if we have a very aggressive business expansion target, with an increasingly good marketing strategy, profits will multiply. The second biggest is YI business with a value of $48.33 \%$, while YF and MK businesses have the smallest amount compared to the others, with only $3.27 \%$ and $4.22 \%$ consecutively.

The difference in the assets indicates the existence of a problem that must be resolved by business actors. There seem business students who can use opportunity during the vacation to focus on their business and make profits. But there are also entrepreneurs who are less 
able to adapt to take advantage of the situation. A small ROA indicates that some entrepreneurs have not been able to manage their assets in increasing sales effectively.

\begin{tabular}{|c|c|c|c|}
\hline \multicolumn{4}{|c|}{ ROE } \\
\hline & Net Profit & Total Capital & ROE \\
\hline & a & $\mathrm{b}$ & $\begin{array}{c}(\mathrm{a} / \mathrm{b}) \mathrm{x} \\
100 \%\end{array}$ \\
\hline YI & $58,000.00$ & $115,000.00$ & $50.43 \%$ \\
\hline $\mathrm{EL}$ & $31,000.00$ & $90,000.00$ & $34.44 \%$ \\
\hline PS & $48,000.00$ & $98,000.00$ & $48.98 \%$ \\
\hline $\mathrm{YN}$ & $20,500.00$ & $130,000.00$ & $15.77 \%$ \\
\hline $\mathrm{MK}$ & $19,000.00$ & $410,000.00$ & $4.63 \%$ \\
\hline YF & $18,000.00$ & $495,000.00$ & $3.64 \%$ \\
\hline $\mathrm{KC}$ & $11,000.00$ & $175,000.00$ & $6.29 \%$ \\
\hline $\mathrm{KR}$ & $49,000.00$ & $89,000.00$ & $55.06 \%$ \\
\hline BS & $45,000.00$ & $135,000.00$ & $33.33 \%$ \\
\hline \multirow[t]{2}{*}{$\mathrm{SH}$} & $39,500.00$ & $186,000.00$ & $21.24 \%$ \\
\hline & $339,000.00$ & $1,923,000.00$ & 2.74 \\
\hline Rata-rata & $33,900.00$ & $192,300.00$ & $27.38 \%$ \\
\hline
\end{tabular}

Based on table 12, the highest value of ROE owned by KR business, $55.06 \%$. The second biggest is YI business with an amount of $50.43 \%$. Both $\mathrm{KR}$ and YI businesses produce and sell food that is very familiar to all people, both children, adolescents, and adults. The food sold is also already very familiar with the size of everyone's wallet. Even such foods, not only for those who have little money but people from the high-income groups also like to enjoy them too; no one has never felt the pleasure of dumplings (pangsit) and cireng in Bandung, except the toddlers. The smallest ROE, 3.64\%, is YF business which focuses on selling specific drink to a specific segment of people.
Although the businesses run during the holiday period, it is evident that the types of business that our students are working on do not have the same financial performance. They will succeed in increasing sales if they have been the right strategy in managing their business. Managerial skills are fundamental especially to attract as many customers as possible. The primary consideration for a successful business is good marketing. It must involve fundamental elements, namely a reliable marketing mix: 1) the place to do trading must be strategic, easily accessible to buyers; 2 ) promotion of product sales must be continuously launched massively through various media, including those currently booming such as social media; 3 ) the price of sales can adjust to situation, so that buyers feel happy and willing to be loyal customers; 4) the product sold must reflect its peculiarities, so that it distinguishes it from products sold by competitors.

From this research, we can understand that the business that gets the most profits is the food staple substitute. This type of business produces the fastest return on capital and allows the perpetrator to expand more widely. The reason is, this type of food business knows no weather changes or seasons. Unlike the case with the bustling contemporary drinks business advertised in current media, it tends to target only certain groups, namely young people.

\section{CONCLUSION}

This research concludes that businesses run by students are good. Their financial statements show no significant problems in running a business. All the companies they operate can make a profit. Besides, businesses also have minimal debts. They run a business mostly from their capital because it is still on a tiny scale and has limited scope. 
From this study, we find that the business sector that most promises big profits is KR. It is because the KR food business produces a staple food substitute. While the most costly one is YF due to its efforts to produce drinks typical of millennial young people that are of less interest to many people. YF requires a lot of resources, such as electricity and equipment for processing, a large budget allocation cannot be reduced because businesses have not implemented the economies of scale.

However, we see that there are still resources that have not been used optimally by entrepreneurs. Some business funds have not been maximally used. That is a problem that we want to resolve so that they can enhance business through the available potential and not going in vain.

With education and direction on campus, we believe that the small businesses that students work on with minimal capital become meaningful learning for them so that later they become strong entrepreneurs in the future. The real business is a land of work that must be pursued with patience and endurance without limits, and we can start since from college.

This study has many limitations, mainly because the respondents we observed were relatively few: 10 student entrepreneurs. Researchers can then add respondents to get a broader picture of student entrepreneurs. Also, the analysis in this study is only descriptive. The next researchers can research with a more complicated analysis with a richer approach.

\section{REFERENCES}

Ambad, S. N. A., \& Damit, D. H. D. A. (2016). Determinants of entrepreneurial intention of pharmacy students in Chennai. Procedia Economics and Finance,
37, 108-114.

Antaranews.com. (2016). Indonesia butuh jutaan wirausaha baru, kata Presiden. Retrieved February 10, 2019, from https://www.antaranews.com/berita/ 562513/indonesia-butuh-jutaanwirausaha-baru-kata-presiden

Aribawa, D. (2016). Pengaruh Literasi Keuangan Terhadap Kinerja Dan Keberlangsungan Umkm Di Jawa Tengah. Journal Siasat Bisnis, 20(1), 1-13. https://doi.org/10.1007/s10006-0130431-4

Asyhari, Pudjihastuti, S. H., \& Kurdaningsih, D. M. (2018). Peran mediasi keunggulan kompetitif pada faktor determinan kinerja bisnis UKM di sentra tenun batik di Jawa Tengah Pendahuluan. Siasat Bisnis, 22(2), 111-131. https://doi.org/10.20885/jsb.vol22.is s2.art1

Budiyanti, H., \& Patiro, S. (2015). IDENTIFICATION OF MAIN ISSUES AFFECTING THE GROWTH OF GRADUATES' SMALL AND MEDIUM ENTERPRISES (SMEs) IN YOGYAKARTA. Jurnal Siasat Bisnis, 19(1), 1-14.

Chadys, P. A. O., Sulung, L. A. K., \& Admeinasthi, M. B. (2018).

Pengaruh Internasionalisasi, Afiliasi Bisnis, dan Research \&amp; Development Terhadap Kinerja Perusahaan Manufaktur di Indonesia. Jurnal Siasat Bisnis, 22(1), 62-75.

https://doi.org/10.20885/jsb.vol22.is s1.art4

Creswell, J. W. (2009). Research Design: Qualitative, Quantitative, and Mixed Methods Approaches. London: SAGE Publications, Inc. Darmawan, B. A. (2018). The loyalty of Muslim customers on the 
Indonesian Islamic banks : the role of corporate image, satisfaction , and trust, 22(2), 132-143. https://doi.org/10.20885/jsb.vol22.is s2.art2

Fatoki, O. (2014). The Entrepreneurial Intention of Undergraduate Students in South Africa: The Influences of Entrepreneurship Education and Previous Work Experience. Mediterranean Journal of Social Sciences, 5(7), 294-299. https://doi.org/10.5901/mjss.2014.v $5 \mathrm{n} 7 \mathrm{p} 294$

Hadinugroho, B., Agustanto, H., \& Harmadi. (2018). Determinan struktur modal perusahaan di negara-negara asia tenggara Pendahuluan. Siasat Bisnis, 22(2), 144-163.

https://doi.org/10.20885/jsb.vol22.is s2.art3

Holik, A., \& Manggala, G. D. (2016). Empirical Evidence of Factors Boosting Entrepreneurial Motivation. Manajemen Usahawan Indonesia, 45(1), 44-54.

Ismanto, H., Aziz, S., \& Irawan, W. (2018). Peran Karakteristik Pemilik , Hubungan Dengan Pelanggan , Komitmen Perilaku , dan Orientasi Usaha Terhadap Kinerja Keuangan UKM. Jurnal Siasat Bisnis, 22(1), 76-91.

https://doi.org/10.20885/jsb.vol22.is s1.art5

Jaswadi, J. (2017). Analisis tingkat implementasi good corporate governance pada usaha kecil dan menengah. Jurnal Siasat Bisnis, 20(2), 161-180.

https://doi.org/10.20885/jsb.vol20.is s2.art5

Kusumawardhani, R. (2018). Pengaruh luas pengungkapan informasi , konsentrasi kepemilikan dan diversifikasi pada biaya modal ekuitas : studi pada perusahaan non-keuangan di indonesia

Pendahuluan, 22(2), 182-202.

https://doi.org/10.20885/jsb.vol22.is s2.art5

Lita, R. P., Meuthia, M., \& Faisal, R. F. (2018). Model Keterkaitan Market Orientation, Leadership, Organizational Innovation dan Organizational Performance pada Industri Kerajinan di Sumatera Barat. Jurnal Siasat Bisnis, 22(1), 38-61. https://doi.org/10.20885/jsb.vol22.is s1.art3

Mufaqih, I. A., Indarti, N., Ciptono, W. S., \& Kartikasari, A. (2017). Pengaruh integrasi, berbagi informasi, dan penundaan pada kinerja rantai pasokan: Studi pada usaha kecil menengah batik di Indonesia. Jurnal Siasat Bisnis, 2l(1), 19-36. https://doi.org/10.20885/jsb.vol21.is s1.art2

Muhammad, A. D., Haneef, M. A., \& Abubakar, I. A. (2013). Entrepreneurial Intention (EI) among Undergraduate Students in International Islamic University Malaysia (IIUM): Empirical Evidence. Australian Journal of Basic and Applied Sciences, 7(October, 12), 184-191. Retrieved from www.ajbasweb.com

Pikiran Rakyat. (2017). Mahasiswa Harus Berani Jajal Wirausaha. Retrieved February 10, 2019, from https://www.pikiranrakyat.com/ekonomi/2017/11/29/m ahasiswa-harus-berani-jajalwirausaha-414809

Prastia, D. O., \& Nursyamsiah, S. (2016). The impact of supply chain operational capability on business performance: empirical finding from small and medium enterprises in Yogyakarta. Siasat Bisnis, 20(1), 90-100. Retrieved from 
https://search.ebscohost.com/login.a spx?direct $=$ true $\& \mathrm{db}=\mathrm{bth} \& \mathrm{AN}=654$ 80101\& site $=$ ehost -

live\%0Ahttps://search.proquest.com $/$ docview $/ 892278431$ ?accountid=10

297\%0Ahttp://resolver.ebscohost.co m/openurl?ctx_ver=Z39.88-

2004\&ctx_enc=info:ofi/enc:UTF8\&rfr_id=info:sid/P

Priyono, A., Nursyamsiah, S., \&

Darmawan, B. A. (2018).

Identifikasi Elemen-Elemen Mikro

Kapabilitas Dinamis Sensing untuk Pengembangan Inovasi di Usaha

Kecil dan Menengah Industri

Kreatif. Siasat Bisnis, 22(1), 92-

109.

https://doi.org/10.20885/jsb.vol22.is s1.art6

Ranto, D. W. P. (2015). Pengaruh

Knowledge Sharing Terhadap

Kemampuan Inovasi Usaha Kecil

Menengah(Ukm) Di Yogyakarta

Dengan Absorptive Capacity

Sebagai Variabel Intervening.

Journal Siasat Bisnis, 19, 132-145.

Setiawan, D. (2018). Karakteristik dewan

komisaris dan manajemen laba :

Bukti pada peristiwa penawaran

saham perdana Pendahuluan, 22(2),

164-181.

https://doi.org/10.20885/jsb.vol22.is

s2.art4

Sivarajah, K. A., \& Achchuthan, S.

(2013). Entrepreneurial intention among undergraduates: Review of literature. European Journal of Business and Management, 5(5), 2222-2839. Retrieved from http://citeseerx.ist.psu.edu/viewdoc/ download?doi=10.1.1.470.9400\&re $\mathrm{p}=\mathrm{rep} 1 \&$ type $=\mathrm{pdf}$

Sutrisno. (2016). Struktur Modal :

Faktor Penentu dan Pengaruhnya pada Nilai Perusahaan. Siasat Bisnis, 20(1), 79-89.

https://doi.org/10.1007/s11199-0099590-z
Syah, D. O., Lupiyoadi, R., \& Tjiptadi, A. P. (2016). Factors affecting the use of e-commerce in creative industries: Empirical evidences from SMES in JabodetabekIndonesia. Jurnal Siasat Bisnis, 20(2), 143-160.

https://doi.org/10.20885/jsb.vol20.is s2.art4

The World Bank. (2008). Doing Business 2009. Washington DC: The World Bank.

The World Bank. (2019). Doing Business 2019: Training for Reform. Washington DC: The World Bank.

Walliman, N., \& Baiche, B. (2001). Your Research Project: A Step-by-Step Guide for the First-Time Researcher. London: SAGE Publications, Inc.

Wijaya, T., Nurhadi, N., \& Kuncoro, A. M. (2015). Intensi berwirausaha mahasiswa: Perspektif pengambilan risiko. Jurnal Siasat Bisnis, 19(2), 109-123. https://doi.org/10.20885/jsb.vol19.is s2.art2 